\title{
ROZWÓJ KONCEPCJI TREŚCI EKONOMICZNEJ (substance) W Stanach ZJednOCZONYCH
}

\begin{abstract}
Streszczenie. Do istotnych wyzwań współczesnego prawa podatkowego należy skuteczne przeciwdziałanie unikaniu opodatkowania. Jednym ze sposobów walki z tym negatywnym zjawiskiem jest poszukiwanie i badanie $\mathrm{w}$ działaniach podatników elementu treści ekonomicznej (ang. substance). Na szczególną uwagę zasługują tu zwłaszcza amerykańskie doktryny orzecznicze, a mianowicie doktryna economic substance oraz doktryna business purpose. Analiza tych doktryn wskazuje, że pojęcie treści ekonomicznej (substance) powinno być rozumiane w kontekście zmiany (poprawy) sytuacji ekonomicznej, finansowej, gospodarczej podatnika, wynikającej z czegoś więcej niż tylko z uzyskanej korzyści podatkowej. Owa zmiana (poprawa) może być przy tym analizowana z dwóch perspektyw - obiektywnej lub subiektywnej. Z perspektywy obiektywnej chodzi o rzeczywistą zmianę (poprawę), mającą odzwierciedlenie w zyskach generowanych przez podatnika. Natomiast z perspektywy subiektywnej chodzi o przekonanie podatnika, że podejmowane działania były nakierowane na realizację konkretnego zamierzenia gospodarczego (osiągnięcie zysku). Kryterium obiektywne, jako niewymagające dokonywania ocen motywów działania podatnika, wydaje się przy tym bardziej mierzalne, a tym samym łatwiejsze do zastosowania w praktyce.
\end{abstract}

Słowa kluczowe: unikanie opodatkowania, treść ekonomiczna, cel gospodarczy

1. WSTĘP

Nie ulega wątpliwości, że współcześnie w prawie podatkowym jednym z najbardziej palących problemów jest skuteczne przeciwdziałanie zjawisku unikania opodatkowania. Rozmaite inicjatywy w tym zakresie są

* Autorka jest radcą prawnym i doradcą podatkowym, managerem w KPMG Tax M. Michna sp.k. 
podejmowane zarówno na poziomie międzynarodowym (OECD, Unia Europejska), jak również w ramach poszczególnych państw. Stosowane rozwiązania mają postać konkretnych zapisów prawnych (np. wprowadzone do porządku wielu krajów klauzule ogólne przeciwko unikaniu opodatkowania), ale również bazują na pewnych koncepcjach nie zawsze skodyfikowanych, a wynikających z dorobku doktryny i orzecznictwa. Jedną z takich koncepcji jest poszukiwanie i badanie w działaniach podatników elementu treści ekonomicznej (ang. substance). Wydaje się, że za najbardziej reprezentatywne dla rozwoju tej koncepcji należałoby uznać Stany Zjednoczone.

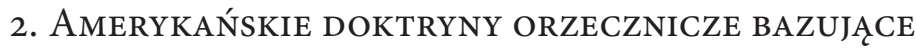
NA KONCEPCJI SUBSTANCE

W Stanach Zjednoczonych już kilkadziesiąt lat temu „wykształciło się szereg koncepcji orzeczniczych - nazywanych doktrynami - które mają na celu stworzenie możliwości dokonywania w miarę obiektywnych ocen, czy podatnik unika opodatkowania w sposób dozwolony, czy też nie"1. Wśród najważniejszych można wymienić: doktrynę economic substance, doktrynę substance over form, doktrynę step transaction, doktrynę business purpose oraz doktrynę shame transaction ${ }^{2}$. Przedmiotem niniejszego opracowania są doktryny koncentrujące się wokół zagadnienia treści ekonomicznej (substance) w prawie podatkowym, tj. doktryna economic substance oraz doktryna business purpose.

Podstawowym założeniem orzeczniczej doktryny economic substance jest przyjęcie, że sąd może odmówić korzyści podatkowych płynących $\mathrm{z}$ transakcji gospodarczej w sytuacji, gdy transakcja ta sama w sobie nie skutkuje uzyskaniem jakichkolwiek korzyści ekonomicznych innych niż oszczędność podatkowa. Doktryna ta wywodzi się z jednego z najgłośniejszych orzeczeń amerykańskiego sądownictwa w sprawach podatkowych - a mianowicie z rozstrzyganej w 1935 r. sprawy Gregory v. Helvering. W celu obniżenia obciążania podatkowego (zapłata niższego podatku od zysków kapitałowych zamiast wyższego podatku dochodowego) podatnik wykorzystał tam korzystne regulacje prawne dotyczące restrukturyzacji spółek. Transakcja została jednak zakwestionowana przez administrację

${ }^{1}$ Por. B. Brzeziński, Anglosaskie doktryny orzecznicze dotyczące unikania opodatkowania, Toruń 1996, s. 23.

${ }^{2}$ Por. P. Lampreave, An Assessment of the Anti-Tax Avoidance Doctrines in the United States and the European Union, „Bulletin for International Taxation” 2012, nr 3, s. 154. 
podatkową, która argumentowała, że działania podatnika w rzeczywistości nie stanowiły reorganizacji działalności gospodarczej, lecz - przy wykorzystaniu odpowiednich form prawnych - miały jedynie stwarzać pozór takiej reorganizacji ${ }^{3}$. W niekorzystnym dla podatnika wyroku Sąd Najwyższy stanął na stanowisku, że

w sytuacji, gdy postanowienia ustaw podatkowych mówią o reorganizacji spółek i ułatwiają tę reorganizację $\mathrm{w}$ drodze znoszenia ograniczeń podatkowych, to dotyczy reorganizacji rzeczywistej. Nie mieszczą się w tych postanowieniach takie działania, które nie mają - jak to było w rozpatrywanej sprawie - z reorganizacją nic wspólnego. $\mathrm{W}$ związku z tym nie można do nich stosować przepisów podatkowych odnoszących się do reorganizacji spółek ${ }^{4}$.

Po orzeczeniu w sprawie Gregory v. Helvering doktryna economic substance była generalnie stosowana w przypadku transakcji, w których podatnik technicznie spełnił wszystkie przewidziane przepisami wymogi formalne, jednak zostało to dokonane w taki sposób, że - jak można przypuszczać - konkretny rezultat danej transakcji (lub szeregu transakcji) nie był przewidziany przez legislatora. Doktryna jest przy tym oparta na dwóch filarach, subiektywnym oraz obiektywnym. Element subiektywny polega na ustaleniu, czy podatnik miał jakiekolwiek cele - inne niż czysto podatkowe - dla zrealizowania danej transakcji. Natomiast element obiektywny koncentruje się na badaniu, czy w wyniku zrealizowania transakcji został osiągnięty jakiekolwiek efekt poza uzyskaniem korzyści podatkowej (gdy np. podatnik realnie nie oczekiwał zysku ekonomicznego z transakcji) ${ }^{5}$.

Subiektywny element doktryny economic substance stanowi, że transakcja posiada treść ekonomiczną, jeśli jest - w racjonalny sposób - powiązana z użytecznym niepodatkowym celem gospodarczym. Test obiektywny stanowi natomiast, że transakcja posiada treść ekonomiczną, jeśli jej skutkiem jest znaczące i dostrzegalne wzmocnienie pozycji

\section{${ }^{3}$ Ibidem, s. 156.}

${ }^{4}$ Por. B. Brzeziński, op. cit., s. 77.

${ }^{5}$ Por. P. Lampreave, op. cit., s. 157. W wyroku w sprawie ACM Partnership v. Commissioner (1998) pojęcie treści ekonomicznej zostało przedstawione w następujący sposób: „prawo podatkowe [...] wymaga, aby zamierzona transakcja posiadała treść ekonomiczną odrębną od korzyści ekonomicznej osiągniętej wyłącznie poprzez obniżenie podatku. Doktryna economic substance znajduje zastosowanie [...] w sytuacji, gdy podatnik próbuje uzyskać korzyść podatkową, niezamierzoną przez Kongres, przy wykorzystaniu transakcji nie służących realizacji jakiegokolwiek celu ekonomicznego innego niż oszczędności podatkowe". Por. C.M. Pietruszkiewicz, Economic Substance and the Standard of Review, „Alabama Law Review” 2009, t. 60, nr 2, s. 342. 
ekonomicznej netto podatnika, wynikające z czegoś innego niż tylko z obniżenia podatków ${ }^{6}$.

Jeśli chodzi o subiektywny element doktryny economic substance, to zgodnie ze stanowiskiem amerykańskiej administracji podatkowej (ang. Internal Revenue Service) stwierdzenie, czy transakcja posiada cel gospodarczy wymaga rozważenia szeregu okoliczności, takich jak:

(i) czy w ogóle istniała możliwość realizacji zysku;

(ii) czy podatnik miał niepodatkowy, gospodarczy powód dla zaangażowania się w transakcję;

(iii) czy podatnik, albo jego doradcy, rozważali lub badali transakcję, z uwzględnieniem ryzyka rynkowego;

(iv) czy podatnik rzeczywiście zaangażował kapitał w daną transakcję;

(v) czy przedsiębiorstwa biorące udział $\mathrm{w}$ transakcji były przedsiębiorstwami odrębnymi i niezależnymi od podatnika oraz prowadziły rzeczywistą działalność gospodarczą zarówno przed jak i po zrealizowaniu transakcji;

(vi) czy wszystkie kroki mające znaczenie w realizacji transakcji zostały przeprowadzone na zasadach rynkowych, a strony realizowały swoje zamierzenia;

(vii) czy transakcja była reklamowana jako optymalizacja podatkowa, w której korzyści podatkowe w znaczący sposób przewyższają rzeczywiste środki zaangażowane przez podatnika ${ }^{7}$.

Próbując wykazać, że powyższe okoliczności - wskazujące na realizację celu gospodarczego - nie zostały spełnione, administracja podatkowa może powoływać się na:

(i) dokumenty i inne dowody świadczące o tym, że realizowane transakcje były sprzedawane jako optymalizacje podatkowe, w których warunki ekonomiczne realizacji transakcji miały ograniczone znaczenie;

(ii) dowody świadczące o tym, że podatnik ani jego doradcy nie badali ryzyka rynkowego przed zaangażowaniem się w transakcję;

(iii) dowody świadczące o tym, że poszczególne elementy składające się na transakcję nie były realizowane na warunkach rynkowych;

(iv) dowody świadcząc o tym, że ostrożny inwestor osiągnąłby lub mógłby osiągnąć podobne cele przy użyciu znacznie prostszych lub bezpośrednich metod ${ }^{8}$.

\footnotetext{
${ }^{6}$ Por. C.M. Pietruszkiewicz, op. cit., s. 343.

${ }^{7}$ Ibidem, s. 348.

${ }^{8}$ Ibidem.
} 
Jeśli chodzi o obiektywny element doktryny economic substance, wymaga on wykazania przez podatnika, że jego sytuacja ekonomiczna została wzmocniona w wyniku zaangażowania się w transakcję. Dla stwierdzenia, że powyższy test został spełniony, nie oczekuje się jednak, aby transakcja prowadziła do realizacji rzeczywistego zysku; badany jest raczej potencjał do realizacji zysku. Przy ocenie tego potencjału stosowany jest standard rozsądnej osoby - w tym przypadku rozsądnego przedsiębiorcy - w celu określenia, czy istnieje taki potencjał do realizacji zysku, aby rozsądny przedsiębiorca zainwestował w przedsięwzięcie, biorąc pod uwagę standardy obowiązujące w określonej gałęzi przemysłu (dla danego typu działalności gospodarczej). Innymi słowy, dla stwierdzenia, że powyższy test został spełniony, transakcja musi być potencjalnie zyskowna"

Podkreślić należy, że obiektywny test doktryny economic substance nie przesądza wprawdzie o odpowiedzialności w oparciu o subiektywne procesy myślowe, jednak nie przewiduje on również korzyści podatkowych w przypadku braku takich przemyśleń. W konsekwencji własna niewiedza nie prowadzi do uzyskania korzyści podatkowych ${ }^{10}$.

Podsumowując, subiektywny i obiektywny filar doktryny economic substance różnią się w jednej zasadniczej kwestii. Mianowicie, obiektywny filar koncentruje się na modelu racjonalnego przedsiębiorcy, oceniając, czy - przy zastosowaniu standardu takiego racjonalnego przedsiębiorcy - w konkretnej gałęzi przemysłu występuje potencjał do realizacji zysku. Natomiast w filarze subiektywnym pytanie sprowadza się do tego, czy podatnik wierzył, że działa w niepodatkowych celach gospodarczych niezależnie od tego, czy standard racjonalnego przedsiębiorcy zostałby spełniony ${ }^{11}$.

Obok doktryny economic substance drugą popularną amerykańską doktryną orzeczniczą nawiązującą do koncepcji treści ekonomicznej (substance) jest doktryna business purpose. Doktryna ta została w sposób jednoznaczny sformułowana w wyroku z 1960 r. w sprawie Knetsch v. United States. W rozstrzyganym stanie faktycznym podatnik zaciągnął od instytucji ubezpieczeniowej dwie pożyczki powiązane $\mathrm{z}$ nabyciem od tejże instytucji obligacji. Od zaciągniętych pożyczek zapłacił z góry odsetki, uzyskując dzięki temu znaczne oszczędności podatkowe przy minimalnym zaangażowaniu własnego kapitału. Ostatecznie Sąd Najwyższy nie uznał jednak prawa podatnika do potrącenia od dochodu zapłaconych odsetek, stwierdzając, że zrealizowana

\footnotetext{
${ }^{9}$ Ibidem, s. 349.

${ }^{10}$ Ibidem, s. 249-350.

${ }^{11}$ Ibidem, s. 365-366.
} 
transakcja nie prowadziła do osiągnięcia jakiegokolwiek celu innego niż uzyskanie oszczędności podatkowych ${ }^{12}$. Zgodnie z doktryną business purpose,

sąd może nie uznać za skuteczną na gruncie prawa podatkowego czynności prawnej, podjętej przez podatnika, jeżeli nie służy ona realizacji jakiegokolwiek celu gospodarczego, a podjęta została wyłącznie w celu obniżenia obciążenia podatkowego bądź uniknięcia podatku w ogóle. W myśl wspomnianej doktryny sąd może także nie akceptować formy zastosowanej przez podatnika do przeprowadzenia określonej operacji gospodarczej, oceniając tę operację przez pryzmat jej treści bądź też rezultatów ekonomicznych. Nie ma przy tym znaczenia fakt, że transakcja była realna, nie zaś pozorna ${ }^{13}$.

Doktryna business purpose była stosowana w amerykańskim orzecznictwie przynajmniej w trzech formułach. Zgodnie z pierwszą z nich - określaną mianem interpretacji ustawowej - sądy badają, czy zgodnie z zamierzeniem ustawodawcy (Kongresu) zastosowanie danej formy zrealizowania transakcji miało skutkować tym, by konkretna transakcja nie podlegała opodatkowaniu. Formuła ta znalazła zastosowanie, przykładowo, w sprawie Horn v. Commissioner ${ }^{14}$. Druga formuła wykorzystywana przez sądy jest oparta o kryterium czysto subiektywne. Formuła ta znalazła, przykładowo, zastosowanie w sprawie Rice’s Toyota World, Inc v. Commissioner. Wśród najistotniejszych ustaleń poczynionych w tej sprawie, a wskazujących na nieposiadanie przez podatnika celu gospodarczego dla zrealizowania badanej transakcji, wskazano m.in. dokumenty posiadane przez podatnika w związku z tą transakcją, a koncentrujące się na możliwych do uzyskania

12 Por. B. Brzeziński, op. cit., s. 78-79. Także A.D. Madison, The Tension Between Textualism and Substance-Over-Form Doctrines in Tax Law, „Santa Clara Law Review” 2003, nr 43, s. 724-725. Jak pisze J. Tiley, schemat badany w sprawie Knetsch obejmował pożyczkę pieniędzy oprocentowaną na poziomie $3,5 \%$ w celu zrealizowania inwestycji o stopie zwrotu na poziomie 2,5\%; powierzchownie taki schemat wydaje się być nieatrakcyjny. To co uczyniło powyższy schemat atrakcyjnym była jednak możliwość opodatkowania zwrotu z inwestycji podatkiem od zysków kapitałowych przy jednoczesnej możliwości odliczenia odsetek od pożyczki w pełnej wysokości. Jak zaznacza J. Tiley, jeśli ktoś zapłaci odsetki (od pożyczki) w wysokości 350000 USD, jednak uzyska w ten sposób odliczenie od dochodu opodatkowanego na poziomie 90\%, koszt takiej operacji wynosi jedynie 35000 USD. Jeśli dalej ktoś zrealizuje zysk (z inwestycji) w wysokości 250000 USD, opodatkowany podatkiem od zysków kapitałowych na poziomie $25 \%$, zysk po opodatkowaniu wyniesie 187500 USD przy koszcie 35000 USD, co ostatecznie pozostawia korzyść z realizacji schematu na poziomie 152500 USD. Por. J. Tiley, Judicial Anti-avoidance Doctrines: the US Alternatives - Part 2, „British Tax Review” 1987, nr 6, s. 223.

${ }^{13}$ Por. B. Brzeziński, op. cit., s. 28.

${ }^{14}$ Por. A.D. Madison, op. cit., s. 728. 
w wyniku jej zrealizowania znacznych odliczeniach podatkowych, a nie na możliwym do zrealizowania zysku ${ }^{15}$. Trzecia formuła, czasami stosowana przez sądy, opiera się wreszcie o test faktycznej bieżącej działalności gospodarczej. Formuła ta znalazła zastosowanie w sprawie United Parcel Service v. Commissioner. Zgodnie z zaprezentowaną w tym wyroku tezą samo poszukiwanie przez UPS oszczędności podatkowych nie oznaczało automatycznie braku celu gospodarczego. Transakcja posiada cel gospodarczy, jeśli mowa o rzeczywiście funkcjonującym przedsiębiorstwie (jak UPS), tak długo, jak działa ono w dobrej wierze prowadząc działalność służącą realizacji zysku' ${ }^{16}$.

W wyroku w sprawie ACM Partnership v. Commissioner (1998) doktryna business purpose została przedstawiona w następujący sposób:

transakcja musi być w sposób racjonalny powiązana z użytecznym niepodatkowym celem, który jest do przyjęcia w świetle działalności prowadzonej przez podatnika oraz użyteczny w świetle sytuacji ekonomicznej i zamierzeń podatnika. Zarówno użyteczność wyznaczonego celu jak i racjonalność środków podjętych w celu jego realizacji muszą być oceniane zgodnie z praktyką handlową i biorąc pod uwagę właściwy sektor przemysłu. Zazwyczaj racjonalny związek pomiędzy celem i środkami podjętymi dla jego osiągnięcia nie będzie stwierdzony, chyba że można w sposób racjonalny oczekiwać, że korzyści niepodatkowe będą co najmniej współmierne do kosztów transakcji1".

W amerykańskim orzecznictwie doktryna economic substance była stosowana w połączeniu $\mathrm{z}$ doktryną business purpose (test łączny) lub niezależnie od niej (test rozłączny). Test łączny wymaga wykazania przez podatnika, że dana transakcja skutkowała uzyskaniem korzyści ekonomicznej (innej niż korzyść podatkowa) oraz że służyła ona realizacji określonego celu gospodarczego ${ }^{18}$. Natomiast w teście rozłącznym - korzystniejszym dla podatnika - wystarczające jest wskazanie na uzyskanie korzyści ekonomicznej lub realizację celu gospodarczego ${ }^{19}$.

${ }^{15}$ Ibidem, s. $728-729$.

${ }^{16}$ Ibidem, s. 729.

${ }^{17}$ Por. C.M. Pietruszkiewicz, op. cit., s. 347.

${ }^{18}$ Test łączny został m.in. zastosowany w orzeczeniu w sprawie Stobie Creek Investments LLC (2008). Por. P. Lampreave, op. cit., s. 158. Także R.M. Lipton, „Codification” of the Economic Substance Doctrine - Much ado about Nothing?, „Journal of Taxation” 2010, nr 6, s. 2.

${ }^{19}$ Test rozłączny został m.in. zastosowany w orzeczeniu w sprawie Rice’s Toyota World Inc (1985). Por. P. Lampreave, op. cit., s. 157. Także R.M. Lipton, op. cit., s. 2. W sprawie Rice’s Toyota przedmiotem orzekania była transakcja, w której podatnik zakupił używany sprzęt komputerowy finansując się pożyczką od firmy leasingowej, a następnie oddał 
Doktryna economic substance została inkorporowana do amerykańskiego Internal Revenue Code (IRC) w 2010 r. na mocy Health Care and Education Reconciliation Act i ma zastosowanie do transakcji, które zostały zrealizowane po 30 marca $2010 \mathrm{r}^{20}$ Zgodnie z definicją zawartą w ustępie 7701 (o) (5) (A) IRC, pojęcie doktryny economic substance oznacza doktrynę systemu common law odmawiającą korzyści podatkowych dla danej transakcji w sytuacji, gdy transakcja ta nie skutkuje uzyskaniem korzyści ekonomicznej (brak economic substance) lub nie posiada celu gospodarczego (brak business purpose). Ustęp 7701 (o) (5) (C) IRC stanowi przy tym, że stwierdzenie, czy doktryna economic substance jest relewantna w odniesieniu do danej transakcji powinno nastąpić w taki sam sposób, w jaki nastąpiłoby, gdyby doktryna ta nie została nigdy skodyfikowana. Pojęcie transakcji zostało natomiast zdefiniowane jako obejmujące także serię transakcji (ustęp 7701 (o) (5) (D) IRC). Przy takim rozumieniu powyższych pojęć ustęp 7701 (o) (1) IRC stanowi, że w odniesieniu do jakiejkolwiek transakcji, dla której doktryna economic substance jest relewantna, transakcja jest traktowana jako posiadająca economic substance pod warunkiem, że (A) zrealizowanie transakcji zmienia w znaczący sposób (nie licząc osiągnięcia określonych skutków podatkowych) sytuację ekonomiczną podatnika oraz (B) podatnik ma zasadniczy powód (inny niż osiągnięcie określonych skutków podatkowych) do zawarcia tej transakcji.

Mając na uwadze powyższe, należy stwierdzić, że inkorporowanie doktryny economic substance do amerykańskiego porządku prawnego nastąpiło w formie testu łącznego (ang. conjunctive test). W konsekwencji takiego podejścia badanie danej transakcji musi zatem obejmować dwa elementy: obiektywne skutki transakcji z perspektywy sytuacji ekonomicznej/ finansowej podatnika oraz subiektywne powody zaangażowania się przez podatnika w transakcję ${ }^{21}$.

$\mathrm{Na}$ zasadzie „strefy bezpieczeństwa” dla podatników - jako chronione przed badaniem z perspektywy economic substance - zostały uznane pewne

tenże sprzęt wspomnianej firmie w leasing (transakcja sprzedaży i leasingu zwrotnego). W wyniku zastosowanej konstrukcji korzyść podatnika polegała na możliwości zaliczenia odsetek od zaciągniętej pożyczki oraz przyspieszonych odpisów amortyzacyjnych do koszów uzyskania przychodów. Transakcja została jednak skutecznie zakwestionowana jako nieprowadząca do uzyskania jakiejkolwiek korzyści ekonomicznej ani nierealizująca jakiegokolwiek celu gospodarczego. Por. A.D. Madison, op. cit., s. 723-724.

${ }^{20}$ Por. Internal Revenue Service, Additional Guidance under the Codified Economic Substance Doctrine and Related Penalties, 10.10.2014, s. 3.

${ }^{21}$ Por. P. Lampreave, op. cit., s. 158. Także R.M. Lipton, op. cit., s. 7. 
podstawowe dla prowadzenia działalności gospodarczej transakcje, takie jak: wybór pomiędzy finansowaniem przedsiębiorstwa kapitałem albo długiem, wybór pomiędzy realizowaniem zagranicznej inwestycji za pośrednictwem podmiotu krajowego albo zagranicznego, decyzja o przystąpieniu do transakcji (lub szeregu transakcji) obejmującej założenie lub reorganizację podmiotu, decyzja o wykorzystaniu przy realizacji transakcji podmiotu powiązanego, jeśli warunki takiej transakcji odpowiadają warunkom rynkowym ${ }^{22}$.

W literaturze skodyfikowanie doktryny economic substance jest zasadniczo oceniane pozytywnie, choćby z uwagi na ostateczne przesądzenie, że doktryna ta powinna być stosowana w formie testu łącznego, a nie - jak pokazywała praktyka niektórych amerykańskich sądów - rozłącznego $^{23}$. Negatywnie natomiast jest oceniany brak zdefiniowania przesłanek zastosowania doktryny economic substance, w szczególności pojęć takich jak: „zmiana w znaczący sposób” sytuacji ekonomicznej podatnika (ang. "change in a meaningful way" of the taxpayer's economic position) oraz istnienie "zasadniczego" powodu - innego niż podatkowy - do zawarcia danej transakcji (ang. „substantial” non-federal tax purpose for entering into a transaction $)^{24}$. Szczególnie jeśli chodzi o drugą z wspomnianych przesłanek, w literaturze wskazuje się, że wymaga ona dokonania subiektywnej analizy intencji podatnika, co w praktyce może być trudne do weryfikacji ${ }^{25}$. Ciężar wykazania zasadniczego - innego niż korzyść podatkowa - motywu zawarcia danej transakcji spoczywałby przy tym na podatniku. Motywem takim mogłoby być wskazanie przez podatnika na „racjonalne oczekiwanie" (ang. reasonable expectation) zrealizowania zysku na badanej transakcji, przy czym wielkość tego spodziewanego zysku musiałaby być znacząca w porównaniu do spodziewanej do uzyskania korzyści podatkowej ${ }^{26}$. „Racjonalne oczekiwanie” zysku miałoby wówczas postać hipotetycznej analizy na moment zawarcia danej transakcji, nie oznaczałoby natomiast konieczności wykazania zysku faktycznie zrealizowanego ${ }^{27}$. Kryteria powyższe - jako bardzo ocenne - wydają się jednak mało przydatne w praktyce

${ }^{22}$ Por. P. Lampreave, op. cit., s. 160. Także The Joint Committee On Taxation, Technical Explanation Of The Revenue Provisions Of The „Reconciliation Act Of 2010”, As Amended, In Combination With The „Patient Protection And Affordable Care Act”, 21.03.2010, s. 152-153, https://www.jct.gov/publications.html?func=startdown\&id=3673.

${ }^{23}$ Por. P. Lampreave, op. cit., s. 158.

${ }^{24}$ Ibidem, s. $158-159$.

${ }^{25}$ Ibidem, s. 159.

${ }^{26}$ Ibidem. Także The Joint Committee On Taxation, op. cit., s. 155.

${ }^{27}$ Por. P. Lampreave, op. cit., s. 159. 
(można przykładowo postawić pytanie, czy nieprzygotowanie przez podatnika biznes planu lub prognozy spodziewanych przychodów powinno być traktowane jako domniemanie próby uniknięcia opodatkowania $)^{28}$.

W literaturze wskazuje się również na ryzyko zbyt szerokiego stosowania ustępu 7701 (o) Internal Revenue Code, w szczególności do działań stanowiących dozwolone planowanie podatkowe, w których kroki motywowane względami podatkowymi stanowią jedynie część większej transakcji. W celu przeciwdziałania powyższemu zjawisku David Hariton proponuje ograniczenie stosowania ustępu 7701 (o) ICR jedynie do optymalizacji podatkowych typu tax shelter. Pod pojęciem tax shelter rozumie przy tym transakcje finansowe generujące odliczenia lub straty podatkowe przy braku jakichkolwiek strat ekonomicznych. Wykreowane w ten sposób odliczenia lub straty są następnie rozliczane z niepowiązanymi z nimi dochodami z innych realizowanych przez podatnika aktywności lub transakcji, „chroniąc” (ang. shelter) te dochody przed opodatkowaniem. Zdaniem D. Haritona, stosowanie ustępu 7701 (o) ICR powinno być ograniczone jedynie do transakcji stanowiących wspomniane wyżej tax shelter. W konsekwencji D. Hariton proponuje uzupełnienie ustępu 7701 (o) ICR poprzez dodanie do obowiązującej regulacji prawnej trzeciego filaru, zgodnie z którym niedozwolone są tylko korzyści podatkowe (odliczenia, straty), które „chronią” dochody/ zyski zewnętrzne w stosunku do działalności gospodarczej podatnika ${ }^{29}$.

4. Podsumowanie

Stany Zjednoczone są krajem, w którym doktryny orzecznicze oparte na koncepcji treści ekonomicznej (substance) rozwinęły się najbardziej. Jak wskazuje się w literaturze, taki stan rzeczy wynika ze specyfiki amerykańskiego systemu politycznego i prawnego, przejawiającej się przewlekłością prac legislacyjnych i brakiem możliwości szybkiego reagowania Kongresu na pojawiające się nadużycia podatkowe ${ }^{30}$.

\section{${ }^{28}$ Ibidem.}

${ }^{29}$ Por. K.C. Burke, Refraiming Economic Substance, „Virginia Tax Review” 2011, nr 31, s. 272-273.

${ }^{30}$ Por. E. Jensen, The Tiley Trilogy and U.S. Anti-avoidance Law, „eJournal of Tax Research" 2014, t. 12, nr 1, s. 80. 
Odnosząc się do obu przedstawionych w niniejszym opracowaniu doktryn orzeczniczych (tj. doktryny economic substance i doktryny business purpose), można generalnie stwierdzić, że pojęcie treści ekonomicznej (substance) powinno być rozumiane w kontekście zmiany/poprawy sytuacji/pozycji ekonomicznej/finansowej/gospodarczej podatnika, wynikającej z czegoś więcej niż tylko z uzyskanej korzyści podatkowej. Owa zmiana/poprawa sytuacji/pozycji podatnika może być przy tym analizowana $z$ dwóch perspektyw - obiektywnej lub subiektywnej. Z perspektywy obiektywnej chodzi o rzeczywistą zmianę/poprawę, mającą odzwierciedlenie w zyskach generowanych przez podatnika. Ewentualnie może także chodzić o potencjał danej transakcji do generowania zysku, oceniany z punktu widzenia rozsądnej osoby (standard rozsądnego przedsiębiorcy). Natomiast z perspektywy subiektywnej chodzi o przekonanie podatnika, że podejmowane działania były nakierowane na realizację konkretnego zamierzenia gospodarczego/osiągnięcie zysku. Kryterium obiektywne - niewymagające dokonywania ocen motywów/pobudek działania podatnika - wydaje się przy tym bardziej mierzalne, a tym samym łatwiejsze do zastosowania w praktyce. Dla oceny, czy dana transakcja została podjęta w celu uniknięcia opodatkowania i - w konsekwencji - podlega zakwestionowaniu, doktryny economic substance i business purpose były przy tym w orzecznictwie stosowane w połączeniu ze sobą (test łączny) lub niezależnie (test rozłączny).

Przez długi czas w orzeczniczej praktyce stosowania doktryny economic substance brakowało jednomyślności odnośnie tego, czy wymaga ona jednoczesnego wykazania w działaniach podatnika elementu obiektywnego i subiektywnego, czy też wystarczające jest spełnienie choćby jednej z powyższych przesłanek. Kwestia ta została ostatecznie rozstrzygnięta na rzecz pierwszego wspomnianego wyżej stanowiska w 2010 r., w związku z inkorporowaniem doktryny economic substance do amerykańskiego prawa stanowionego. W konsekwencji takiego podejścia badanie danej transakcji musi obejmować dwa elementy: obiektywne skutki transakcji z perspektywy sytuacji ekonomicznej/finansowej podatnika oraz subiektywne powody zaangażowania się przez podatnika w transakcję. Nie udało się zatem odejść od testu subiektywnego, wymagającego analizy intencji podatnika, co wprowadza przy stosowaniu doktryny element ocenny - a zatem trudny do weryfikacji. 


\title{
BIBLIOGRAFIA
}

Brzeziński B., Anglosaskie doktryny orzecznicze dotyczące unikania opodatkowania, Toruń 1996.

Burke K.C., Refraiming Economic Substance, „Virginia Tax Review” 2011, nr 3.

Internal Revenue Service, Additional Guidance under the Codified Economic Substance Doctrine and Related Penalties, 10.10.2014.

Jensen E., The Tiley Trilogy and U.S. Anti-avoidance Law, „eJournal of Tax Research” 2014, t. 12 , $\mathrm{nr} 1$.

The Joint Committee On Taxation, Technical Explanation Of The Revenue Provisions of The "Reconciliation Act Of 2010", As Amended, In Combination With The "Patient Protection And Affordable Care Act", 21.03.2010.

Lampreave P., An Assessment of the Anti-Tax Avoidance Doctrines in the United States and the European Union, „Bulletin for International Taxation” 2012, nr 3.

Lipton R.M., „Codification” of the Economic Substance Doctrine - Much ado about Nothing?, "Journal of Taxation” 2010, nr 6.

Madison A.D., The Tension Between Textualism and Substance-Over-Form Doctrines in Tax Law, „Santa Clara Law Review” 2003, nr 43.

Pietruszkiewicz C.M., Economic Substance and the Standard of Review, „Alabama Law Review" 2009, t. 60, nr 2.

Tiley J., Judicial Anti-avoidance Doctrines: the US Alternatives - Part 2, „British Tax Review" 1987, nr 6.

\begin{abstract}
An important challenge of the modern tax law is efficient countering of tax avoidance. One of the ways of tackling this problem is investigating and examining of taxpayers' activities from the perspective of their economic substance. Especially interesting from this perspective seem the American judicial doctrines, in particular the economic substance doctrine and the business purpose doctrine. An analysis of the abovementioned doctrines indicates that the concept of economic substance should be interpreted in the context of a change (improvement) of the taxpayer's economic/ financial/ commercial situation resulting from something more than an obtained tax benefit. Such change (improvement) of the taxpayer's situation may be analyzed from two perspectives - objective and subjective. The objective perspective concentrates on an actual change (improvement) reflected in the amount of income generated by the taxpayer. On the other hand the subjective perspective concentrates on the taxpayer's belief that the undertaken actions were aimed at the realization of a specific business goal (generation of profit). The objective perspective as not requiring a judgement of the taxpayer's motives (intentions) seems however more measurable and thus more feasible to apply in practice.
\end{abstract}

Keywords: tax avoidance, economic substance, business purpose 